http://jmscr.igmpublication.org/home/

ISSN (e)-2347-176x ISSN (p) 2455-0450

crossref DOI: https://dx.doi.org/10.18535/jmscr/v8i3.12

IGM Publication Journal Of Medical Science And Clinical Research

\title{
The assessment of the occurrence of metabolic syndrome among postmenopausal women
}

\section{Authors
Dr Shwetha B.M.*, Dr Sharath Kumar D Shah, Dr Muddarangappa R, Dr Annee Vylene Lyngdoh

Sri Siddhartha Medical College Hospital \& Research Centre, Agalakote, Tumakuru, Karnataka-572107

*Correspondence Author

Dr Shwetha B.M.

Junior Resident, Department of General Medicine, Sri Siddhartha Medical College Hospital \& Research

Centre, Tumakuru, Karnataka, India

\begin{abstract}
Background: The menopausal state may be a potential risk factor for the development of metabolic Syndrome as its prevalence has been reported to increase after the attainment of menopause 1. Metabolic Syndrome (MS) has been demonstrated as a common precursor to the development of diabetes and cardiovascular disease (CVD) as well as a risk factor for all cause mortality. Therefore to prevent cardiovascular diseases there is a need to evaluate the occurrence of metabolic Syndrome and its components from the time of the menopause.
\end{abstract}

Aims and Objectives: To determine the frequency of metabolic Syndrome in postmenopausal women and to evaluate the components of metabolic Syndrome in post menopausal women.

Methods: All data for the proposed descriptive study was collected from the patients presenting to the Department of General Medicine, Sri Siddhartha Medical College Hospital \& Research centre, Tumkur. Post menopausal women who had at least 1 year history of cessation of menses were included. clinical examination, anthropometry and other investigations (Body height, Body weight, Waist circumference (WC), Body Mass Index(BMI), Lipid profile, Fasting blood sugar, Blood pressure were done. Post Menopausal women were considered to have Metabolic Syndrome (MS) if they have any three or more of the features according to the modified ATP III Criteria.

Results: Metabolic Syndrome was present in $62.5 \%$ of postmenopausal women and was absent in $37.5 \%$ of post menopausal women. Abdominal obesity (68.3\%) was the most prevalent component of metabolic Syndrome followed by low HDL(53.8\%), high BP(51\%), hypertriglyceridemia (44.2\%) and abnormal FBS (39.4\%). Waist circumference, FBS,BP, triglycerides were significantly higher and HDL was significantly lower in postmenopausal women with metabolic Syndrome. Maximum correlation of MS was found with FBS (odds ratio - 11.56) and least correlation was found with blood pressure (odds ratio - 2.679).

Conclusion: The prevalence of metabolic Syndrome was high in our study. The components of metabolic Syndrome such as waist circumference, FBS, blood pressure, triglycerides were significantly raised and HDL levels were significantly reduced in post menopausal women with metabolic Syndrome. Such a high prevalence of metabolic Syndrome in postmenopausal women is an alarming sign. Lifestyle changes, early detection and treatment of elevated fasting blood glucose, hypertension and hyperlipidemia are necessary for prevention of cardiovascular diseases in women reaching menopause.

Keywords: metabolic Syndrome, menopause. 


\section{Introduction}

Metabolic Syndrome (MS) is described by the clustering of several risk factors for cardiovascular disease (CVD) such as hypertension, dyslipidemia, obesity (particularly central obesity), insulin resistance, and high fasting plasma glucose ${ }^{2}$. The menopausal state may be a potential risk factor for the development of metabolic Syndrome as its prevalence has been reported to increase after the attainment of menopause ${ }^{1}$. The declining level of estrogen and alteration of its ratio with testosterone has been implicated as a causal factor for the emergence of metabolic Syndrome at menopausal transition ${ }^{3}$. But there are also direct effects of estrogen deficiency on body fat distribution (central obesity), insulin action, the arterial wall, and fibrinolysis that may influence cardiovascular risk.

Metabolic Syndrome (MS) has been demonstrated as a common precursor to the development of type 2 diabetes and cardiovascular disease (CVD) as well as a risk factor for all cause mortality.

Accumulation of excess abdominal fat with transition through the menopause plays a central role in connecting the metabolic Syndrome with the metabolic alterations of menopause. Therefore to prevent cardiovascular diseases there is a need to evaluate the occurrence of metabolic Syndrome and its components from the time of the menopause. Understanding of these metabolic changes with menopause will aid in the recognition and treatment of women at risk for future CVD, leading to appropriate interventions.

\section{Definition criteria for Metabolic Syndrome}

Modified National cholesterol Education Program Adult Treatment Panel III [NCEP ATP III criteria ${ }^{4}$ (Waist circumference-Ethnic Specific)

Three or more of the following:

A Central obesity: Waist circumference $\geq 80 \mathrm{~cm}$ in women, $\geq 90 \mathrm{~cm}$ in men (For South Asians)

b. Hypertriglyceridemia: Serum triglycerides level $\geq 150 \mathrm{mg} / \mathrm{dL}$ or specific medication c. Low HDL Cholesterol <50mgldl for women, $<40 \mathrm{mg} / \mathrm{dL}$ for men or specific medication

d. High blood pressure: SBP $\geq 130 \mathrm{mmHg}$ and /or DBP $\geq 85 \mathrm{mmHg}$ or on treatment for hypertension e. High fasting glucose: Serum glucose level $\geq$ $100 \mathrm{mg} / \mathrm{dL}$ or on treatment for diabetes (type2)

\section{Aims and Objectives of the study:}

To determine the frequency of metabolic Syndrome in postmenopausal women and to evaluate the components of metabolic Syndrome in post menopausal women.

\section{Materials and Methods}

A Cross-sectional study was conducted in 104 postmenopausal women visiting general medicine department at Siddhartha medical college and research centre, Tumkur. Over a period of 24 months.

\section{Inclusion Criteria}

Postmenopausal women willing to give consent to participate in the study

\section{Exclusion Criteria}

Surgical menopause, patients on hormone replacement therapy, known Diabetic or Hypertensive before the onset of menopause, patient on lipid lowering medication, history of Ischemic heart disease.

\section{Methods of collection of data}

Post menopausal women who had at least 1 year history of cessation of menses were included after taking written informed consent. This was followed by thorough clinical examination, anthropometry and investigations (Body height, Body weight, Waist circumference (WC) in centimetre, Body Mass Index (BMI), Lipid profile, Fasting blood sugar, Blood pressure)

Post Menopausal women were considered to have metabolic Syndrome if they have any three or more of the features according to the modified ATP III Criteria ${ }^{4}$

a) Abdominal obesity: waist circumference $>80 \mathrm{~cm}$

b) Hypertriglyceridemia: serum triglycerides level $>150 \mathrm{mg} / \mathrm{dl}$ 
c) Low HDL-cholesterol : $<50 \mathrm{mg} / \mathrm{dl}$

d) High blood pressure: SBP $>130 \mathrm{mmh}$ and /or DBP $>85 \mathrm{~mm}$ hg or on treatment for hypertension

e) High fasting glucose: serum glucose level > $100 \mathrm{mg} / \mathrm{dl}$ or on treatment for diabetes

Data was entered in excel sheet and statistical analysis was carried out using SPSS (version 20).To analyze and test data, chi-square test and sample $\mathrm{t}$ test was used. $\mathrm{P}$ value $<0.05$ was considered as statistically significant.

\section{Results}

Graph 1 shows the number of postmenopausal women with metabolic Syndrome. Metabolic Syndrome was present in 65(62.5\%) post menopausal women and absent in $39(37.5 \%)$ post menopausal women.

Table 1 shows the distribution of components of metabolic Syndrome. Waist circumference $>80 \mathrm{~cm}$ (68.3\%) was the most prevalent component of metabolic syndrome followed by HDL <50 mgl dl (53.8\%), BP >130/85mmhg (51\%), Triglycerides $>150 \mathrm{mg} / \mathrm{dl}(44.2 \%)$ and FBS $>100 \mathrm{mg} / \mathrm{dl}(39.4 \%)$

Table 2 shows the distribution of metabolic Syndrome among postmenopausal women according to age. There was high statistical association found between the age and risk of metabolic Syndrome. Maximum prevalence of metabolic Syndrome was found between 56-60 years and minimum prevalence was between 41 45 years.

Table 3 shows the distribution of metabolic Syndrome according to number of years since menopause. There was high statistical association found between metabolic Syndrome and post menopausal duration. Higher the duration of menopause higher was the risk of Metabolic Syndrome. More number of cases with MS was found in the cases whose postmenopausal duration was between 6-10 years

Table 4 shows the distribution of metabolic Syndrome according to BMI. As BMI increased in postmenopausal women, the proportion of metabolic Syndrome increased.

Table 5 shows the comparison of Age, Age of menopause, Height, Weight and BMI of study group with and without Metabolic Syndrome. In our study the mean age of postmenopausal women with metabolic Syndrome was 55.4 \pm 7.27 years and without metabolic Syndrome was 52.28 \pm 9.94 years. There was no significant difference found ( $p=0.074)$ in terms of age between the two groups Table 6 shows the components of metabolic Syndrome among postmenopausal women.

Table 7 and 8 show the comparision of biochemical profile, waist circumference and blood pressure in postmenopausal women with and without metabolic Syndrome.

Table 1: Distribution of components of metabolic Syndrome

\begin{tabular}{|l|c|}
\hline Components of metabolic Syndrome & Number of patients and \% \\
\hline Waist circumference $>\mathbf{8 0 c m}$ & $71(68.3 \%)$ \\
\hline HDL <50 $\mathbf{~ m g / d l ~}$ & $56(53.8 \%)$ \\
\hline BP > 130/85 mmhg or on treatment for Hypertension & $53(51 \%)$ \\
\hline Triglycerides > 150mg/dl & $46(44.2 \%)$ \\
\hline FBS $>\mathbf{1 0 0 m g / d l ~ o r ~ o n ~ t r e a t m e n t ~ f o r ~ d i a b e t e s ~}$ & $41(39.4 \%)$ \\
\hline
\end{tabular}

Table 2: Distribution of metabolic Syndrome according to age

\begin{tabular}{|l|c|c|c|}
\hline \multirow{2}{*}{ Age Group } & \multicolumn{2}{|c|}{ Metabolic Syndrome } & \multirow{2}{*}{ Total } \\
\cline { 2 - 3 } & Absent & Present & \\
\hline $41-45$ & $7(70 \%)$ & $3(30.0 \%)$ & $10(100.0 \%)$ \\
\hline $46-50$ & $19(54.3 \%)$ & $16(45.7 \%)$ & $35(100.0 \%)$ \\
\hline $51-55$ & $6(26.1 \%)$ & $17(73.9 \%)$ & $23(100.0 \%)$ \\
\hline $56-60$ & $1(5.9 \%)$ & $16(94.1 \%)$ & $17(100.0 \%)$ \\
\hline$>60$ & $6(31.6 \%)$ & $13(68.4 \%)$ & $19(100.0 \%)$ \\
\hline Total & $39(37.5 \%)$ & $65(62.5 \%)$ & $104(100.0 \%)$ \\
\hline
\end{tabular}

Chi-Square: 17.528a; P-value: 0.002 
Table 3: Distribution of metabolic Syndrome according to number of years since menopause

\begin{tabular}{|l|c|c|c|}
\hline \multirow{2}{*}{$\begin{array}{l}\text { Number of years since } \\
\text { menopause }\end{array}$} & \multicolumn{2}{|c|}{ Metabolic syndrome } & \multirow{2}{*}{ Total } \\
\cline { 2 - 3 } & Absent & Present & \\
\hline$<2$ years & $12(70.6 \%)$ & $5(29.4 \%)$ & $17(100.0 \%)$ \\
\hline 3 - 5 years & $14(63.6 \%)$ & $8(36.4 \%)$ & $22(100.0 \%)$ \\
\hline 6 - 10 years & $7(19.4 \%)$ & $29(80.6 \%)$ & $36(100.0 \%)$ \\
\hline$>10$ years & $6(20.7 \%)$ & $23(79.3 \%)$ & $29(100.0 \%)$ \\
\hline Total & $39(37.5 \%)$ & $65(62.5 \%)$ & $104(100.0 \%)$ \\
\hline
\end{tabular}

Chi-Square: 22.857a; P-value: $<0.001$

Table 4: Distribution of metabolic Syndrome according to BMI

\begin{tabular}{|l|c|c|c|}
\hline \multirow{2}{*}{ BMI $\left(\mathbf{k g} / \mathbf{m}^{2}\right)$} & \multicolumn{2}{|c|}{ Metabolic syndrome } & \multirow{2}{*}{ Total } \\
\cline { 2 - 3 } & Absent & Present & \\
\hline $18.5-22.9$ & $26(68.4 \%)$ & $12(31.6 \%)$ & $38(100.0 \%)$ \\
\hline $23.0-24.9$ & $12(41.4 \%)$ & $17(58.6 \%)$ & $29(100.0 \%)$ \\
\hline $25.0-29.9$ & $1(3.1 \%)$ & $31(96.9 \%)$ & $32(100.0 \%)$ \\
\hline$>=30$ & $0(0.0 \%)$ & $5(100.0 \%)$ & $5(100.0 \%)$ \\
\hline Total & $39(37.5 \%)$ & $65(62.5 \%)$ & $104(100.0 \%)$ \\
\hline
\end{tabular}

Chi-Square: 34.821 , P-value: $<0.001$

Table 5: Comparison of Age, Age of menopause, Height, Weight and BMI of study group with and without Metabolic Syndrome

\begin{tabular}{|l|c|c|c|c|}
\hline Parameters & $\begin{array}{c}\text { Women with Metabolic } \\
\text { Syndrome (65) } \\
(\text { Mean } \pm \text { S.D) }\end{array}$ & $\begin{array}{c}\text { Women without Metabolic } \\
\text { Syndrome (39) } \\
(\text { Mean } \pm \text { S.D) }\end{array}$ & $\begin{array}{c}\text { Mean } \\
\text { Difference }\end{array}$ & P-value \\
\hline Age & $55.34 \pm 7.27$ & $52.28 \pm 9.94$ & -3.06 & 0.074 \\
\hline Age of Menopause & $45.43 \pm 2.3$ & $45.38 \pm 2.65$ & -0.05 & 0.926 \\
\hline Height & $154.25 \pm 5.81$ & $154.95 \pm 4.61$ & 0.70 & 0.522 \\
\hline Weight & $61.23 \pm 8.55$ & $52.49 \pm 5.63$ & -8.74 & $<0.001$ \\
\hline BMI & $25.68 \pm 2.67$ & $21.82 \pm 1.81$ & -3.86 & $<0.001$ \\
\hline
\end{tabular}

Table 6: Components of Metabolic Syndrome

\begin{tabular}{|c|c|c|c|c|c|c|}
\hline \multirow{2}{*}{$\begin{array}{l}\text { Components of } \\
\text { metabolic Syndrome }\end{array}$} & \multicolumn{2}{|c|}{ Metabolic Syndrome } & \multirow{2}{*}{ Total } & \multirow{2}{*}{$\begin{array}{l}\text { OR(odds } \\
\text { ratio) }\end{array}$} & \multirow{2}{*}{$95 \% \mathrm{CI}$} & \multirow{2}{*}{$\begin{array}{c}\text { P- } \\
\text { Value }\end{array}$} \\
\hline & Absent & Present & & & & \\
\hline \multicolumn{7}{|l|}{ Waist circumference } \\
\hline$<80 \mathrm{~cm}$ & $23(59.0 \%)$ & $10(15.4 \%)$ & $33(31.7 \%)$ & \multirow{2}{*}{7.91} & \multirow{2}{*}{$3.13-19.99$} & \multirow{2}{*}{$<0.001$} \\
\hline$>80 \mathrm{~cm}$ & $16(41.0 \%)$ & $55(84.6 \%)$ & $71(68.3 \%)$ & & & \\
\hline \multicolumn{7}{|c|}{ FBS or Diabetic on medication } \\
\hline$<100 \mathrm{mg} / \mathrm{dl}$ & $35(89.7 \%)$ & $28(43.1 \%)$ & $63(60.6 \%)$ & \multirow{2}{*}{11.56} & \multirow{2}{*}{$3.68-36.34$} & \multirow{2}{*}{$<0.001$} \\
\hline$>100 \mathrm{mg} / \mathrm{dl}$ & $4(10.3 \%)$ & $37(56.9 \%)$ & $41(39.4 \%)$ & & & \\
\hline \multicolumn{7}{|c|}{ BP or hypertensive on $\mathbf{R x}$} \\
\hline$<130 / 85$ & $25(64.1 \%)$ & $26(40.0 \%)$ & $51(49.0 \%)$ & \multirow{2}{*}{2.679} & \multirow{2}{*}{$1.18-6.09$} & \multirow{2}{*}{0.025} \\
\hline$>130 / 85$ & $14(35.9 \%)$ & $39(60.0 \%)$ & $53(51.0 \%)$ & & & \\
\hline \multicolumn{7}{|l|}{ Triglycerides } \\
\hline$<150 \mathrm{mg} / \mathrm{d}$ & $32(82.1 \%)$ & $26(40.0 \%)$ & $58(55.8 \%)$ & \multirow{2}{*}{6.86} & \multirow{2}{*}{$2.64-17.85$} & \multirow{2}{*}{$<0.001$} \\
\hline$>150 \mathrm{mg} / \mathrm{d}$ & $7(17.9 \%)$ & $39(60.0 \%)$ & $46(44.2 \%)$ & & & \\
\hline \multicolumn{7}{|l|}{ HDL } \\
\hline$>50 \mathrm{mg} / \mathrm{dl}$ & $26(66.7 \%)$ & $22(33.8 \%)$ & $48(46.2 \%)$ & \multirow{2}{*}{3.91} & \multirow{2}{*}{$1.69-9.06$} & \multirow{2}{*}{0.002} \\
\hline$<50 \mathrm{mg} / \mathrm{dl}$ & $13(33.3 \%)$ & $43(66.2 \%)$ & $56(53.8 \%)$ & & & \\
\hline Total & $39(100.0 \%)$ & $65(100.0 \%)$ & $104(100.0 \%)$ & & & \\
\hline
\end{tabular}


Table 7: Biochemical Profile

\begin{tabular}{|l|c|c|c|c|}
\hline $\begin{array}{l}\text { Laboratory } \\
\text { Parameters }\end{array}$ & $\begin{array}{c}\text { Women without } \\
\text { Metabolic Syndrome (39) } \\
\text { (Mean } \pm \text { S.D) }\end{array}$ & $\begin{array}{c}\text { Women with Metabolic } \\
\text { Syndrome (65) } \\
\text { (Mean } \pm \text { S.D) }\end{array}$ & $\begin{array}{c}\text { Mean } \\
\text { Difference }\end{array}$ & P-value \\
\hline FBS $(\mathrm{mg} / \mathrm{dl})$ & $91.13 \pm 10$ & $112.18 \pm 30.94$ & -21.06 & $<0.001$ \\
\hline Triglycerides & $133.92 \pm 39.26$ & $168.85 \pm 74.05$ & -34.93 & 0.008 \\
\hline HDL & $53.36 \pm 11.96$ & $47.98 \pm 9.49$ & 5.38 & 0.013 \\
\hline
\end{tabular}

Table 8: Waist circumference and Blood pressure measurement

\begin{tabular}{|l|c|c|c|c|}
\hline Clinical Parameters & $\begin{array}{c}\text { Women without Metabolic } \\
\text { Syndrome (39) } \\
\text { (Mean } \pm \text { S.D) }\end{array}$ & $\begin{array}{c}\text { Women with Metabolic } \\
\text { Syndrome (65) } \\
\text { (Mean } \pm \text { S.D) }\end{array}$ & $\begin{array}{c}\text { Mean } \\
\text { Difference }\end{array}$ & P-value \\
\hline Waist circumference & $79.69 \pm 7.08$ & $89.22 \pm 8.04$ & -9.52 & $<0.001$ \\
\hline SBP & $123.59 \pm 16.21$ & $131.88 \pm 16.91$ & -8.29 & 0.016 \\
\hline DBP & $79.54 \pm 9.67$ & $84.8 \pm 11.21$ & -5.26 & 0.017 \\
\hline
\end{tabular}

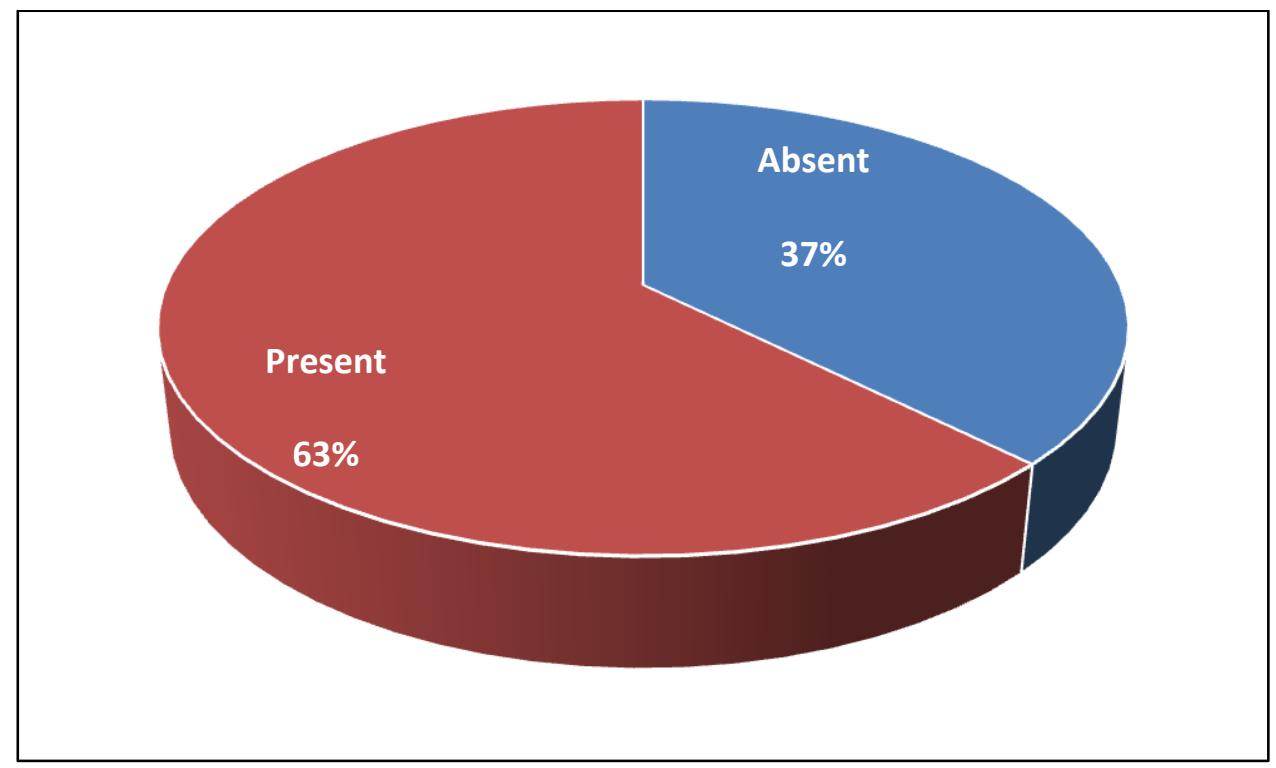

Graph 1: Number of postmenopausal women with metabolic syndrome

\section{Discussion}

\section{Age and Metabolic Syndrome}

The mean age of post menopausal women in our study was $54.19 \pm 8.454$ years and the mean age of menopause was $45.41 \pm 2.428$ years. Metabolic Syndrome was found to be maximum in the women between the age group of 56-60 years (table 2) and who were 6-10 years postmenopausal. (Table 3 ). In a study conducted by Jeyasheela $\mathrm{k}$ et $\mathrm{al}^{5}$ and Jouyandeh $\mathrm{k}$ et $\mathrm{al}^{6}$, the mean age of subjects was comparable to our results

\section{Prevalence of metabolic Syndrome}

The prevalence of metabolic Syndrome in our study was $62.5 \%$ using modified ATP III criteria. Our findings were consistent with studies conducted by Pandey $\mathrm{S}$ et $\mathrm{al}^{7}$, Sharma $\mathrm{S}$ et $\mathrm{al}^{8}$, Heidari R et $\mathrm{al}^{9}$, Figueiredo et al ${ }^{10}$ where postmenopausal women were found to be at higher risk of MS than premenopausal women.

A cross-sectional study Gorgan province in Iran showed a prevalence of $30 \%$ in postmenopausal women $^{11}$, the studies conducted by Tandon VR et $\mathrm{al}^{12}$ (India), Janssen $\mathrm{I}^{13},(\mathrm{US})$, Ruan $\mathrm{X}^{14}$ (China) showed a prevalence of $13 \%, 13.7 \%$ and $33.7 \%$ respectively which is in contrast to our findings.

\section{Components of metabolic Syndrome}

In a study conducted by Jeyasheela $\mathrm{K}$ et $\mathrm{al}^{5}$ dyslipidemia was observed in nearly $83 \%$ of study subjects followed by abnormal FBS $(59.7 \%)$ and hypertension $(50.6 \%)$. 
In a study conducted by Jouyandeh et $\mathrm{al}^{6}$ in Tehran, the percentage of fasting blood sugar $>110$ $\mathrm{mg} / \mathrm{dl}$, high density lipoprotein $<50 \mathrm{mg} / \mathrm{dl}$, Triglyceride $\geq 150 \mathrm{mg} / \mathrm{dl}$, waist circumference $\geq 88$ $\mathrm{cm}$, and systolic blood pressure $\geq 130$ $\mathrm{mmHg}$ /diastolic blood pressure $\geq 85 \mathrm{mmHg}$ in postmenopausal women were $29.1 \%, 35.6 \%$, $35.6 \%, 64.3 \%, 47.9 \%$ respectively which can be compared to our results.

Waist circumference and metabolic Syndrome

In a study conducted by Jayasheela $\mathrm{k}$ et $\mathrm{al}^{5}$ the mean waist circumference of women with and without metabolic Syndrome was $95.63 \pm 9.32 \mathrm{~cm}$ and $86.35 \pm 13.95 \mathrm{~cm}$ respectively. The prevalence of abdominal obesity in a study conducted by Jouyandeh et $\mathrm{al}^{6}$ was $64.3 \%$ which can be compared to our results.

\section{FBS and metabolic Syndrome}

The prevalence of abnormal FBS in our study was $39.4 \%$. Postmenopausal women with metabolic Syndrome had significantly higher fasting blood sugar levels when compared to women without metabolic Syndrome $(\mathrm{p}<0.001)$

The prevalence of abnormal FBS in studies conducted by Jesmin $\mathrm{S}$ et $\mathrm{al}^{15}$ and Marjani et al ${ }^{11}$ was $49.64 \%$ and $17 \%$ respectively.

\section{Blood pressure and Metabolic Syndrome}

In our study, the prevalence of BP $>130 / 85 \mathrm{mmhg}$ was $51 \%$. In a study conducted by Jayasheela $\mathrm{K}$ et $\mathrm{al}^{5}$, post menopausal women with metabolic Syndrome had significantly higher systolic blood pressure $(\mathrm{p}=0.002)$ when compared to women without metabolic Syndrome. However there was no difference in diastolic blood pressure between two groups. There was a high prevalence of hypertension in our study and the study conducted by Jayasheela $\mathrm{K}$ et $\mathrm{al}^{5}$, Jouyandeh et $\mathrm{al}^{6}$ and Marjani et $\mathrm{al}^{11}$.

\section{Lipid profile and metabolic Syndrome}

The prevalence of hypertriglyceridemia in our study was $44.2 \%$ and the prevalence of low HDL in post menopausal women was $53.8 \%$. There was significant association between dyslipidemia and metabolic syndrome (table 6 and table 7)
In a study conducted by Jeyasheela $\mathrm{K}$ et al, there was no significant association between dyslipidemia and metabolic Syndrome, but there was significant association between dyslipidemia and metabolic Syndrome in a study conducted by Marjani et al.

\section{Limitations of the study}

1) It is not a case control study:

2) Criteria used to define metabolic Syndrome- There are different criterias used to define metabolic Syndrome.

\section{Conclusion}

The prevalence of metabolic Syndrome was high in our study. The components of metabolic Syndrome such as waist circumference, FBS, blood pressure, triglycerides were significantly raised and HDL levels were significantly reduced in post menopausal women with metabolic Syndrome. Such a high prevalence of metabolic Syndrome in postmenopausal women is an alarming sign. Prevention through c lifestyle changes or early detection and treatment of elevated fasting blood glucose, hypertension and hyperlipidemia are necessary for prevention of cardiovascular diseases in women reaching menopause. Post menopausal should be considered as a major target group for prevention of metabolic Syndrome.

\section{Acknowledgement: Nil}

Financial Support: Nil

\section{References}

1. Petri Nahas EA, Padoani NP, Nahas-Neto J, Orsatti FL, Tardivo AP, Dias R. Metabolic syndrome and its associated risk factors in Brazilian postmenopausal women. Climacteric J Int Menopause Soc. 2009 Oct; $12(5): 431-8$

2. Miranda PJ, De Fronzo RA, Califf RM, Guyton JR. Metabolic Syndrome: definition, pathophysiology, and 
mechanisms. American Heart Journal. 2005 149(1):33-45.

3. Mesch VR, Boero LE, Siseles NO, Royer M, Prada M, Sayegh F, et al. Metabolic syndrome throughout the menopausal transition: influence of age and menopausal status. Climacteric. 2006;9(1):40-8.

4. Grundy SM, Cleeman JI, Daniels SR, Donato KA, Eckel RH, Franklin BA, Gordon DJ, Krauss RM, Savage PJ, Smith SC Jr. et al.Diagnosis and management of the metabolic Syndrome: an American Heart Association/National Heart, Lung, and Blood Institute Scientific Statement. Circulation. 2005;112:2735-2752

5. Jayasheela K, Ebenezer D, Vaibhav L, Thomas V, Bijesh Y, Kekre A. Prevalence of metabolic Syndrome among postmenopausal women in South India. Int J Reprod Contracept Obstet Gynecol. 2018 Jun;7(6):2364-2370

6. Jouyandeh Z, Nayebzadeh F, Qorbani M, Asadi M. Metabolic syndrome and menopause. Journal of diabetes and metabolic disorders. 2013 Jan 3;12:1.

7. Pandey S, Srinivas M, Agashe S, Joshi J, Galvankar P, Prakasam CP et al. Menopause and metabolic Syndrome: A study of 498 urban women from western India.J Midlife Health. 2010 Jul-Dec; 1(2): 63-69

8. Sharma S, Aggarwal N, Joshi B, Suri V, Badada S. Prevalence of metabolic Syndrome in pre- and postmenopausal women: A prospective study from apex institute of North India. J Mid-life Health 2016; 7:169-74.
9. Heidari R, Sadeghi M, Talaei M, Rabiei K, Mohammadifard N, Sarrafzadegan N. Metabolic syndrome in menopausal transition: Isfahan Healthy Heart Program, a population based study. Diabetol Metab Syndr 2010;2:59

10. Figueiredo Neto JA, Figuerêdo ED, Barbosa JB, Barbosa Fde F, Costa GR, Nina VJ, et al. Metabolic syndrome and menopause: Cross-sectional study in gynecology clinic. Arq Bras Cardiol 2010;95:339-45

11. Marjani A, Moghasemi S. The Metabolic Syndrome among Postmenopausal Women in Gorgan. Int J Endocrinol. 2012; 2012:953627.

12. Tandon VR, Mahajan A, Sharma S, Sharma A. Prevalence of cardiovascular risk factors in postmenopausal women: A rural study. J Mid life Health 2010;1:26-9

13. Janssen I, Powell LH, Crawford S, Lasley B, Sutton-Tyrrell K. Menopause and the metabolic Syndrome: The Study of Women's Health Across the Nation. Arch Intern Med 2008;168:1568-75

14. Ruan X, Jin J, Hua L, Liu Y, Wang J, Liu $\mathrm{S}$. The prevalence of metabolic Syndrome in Chinese postmenopausal women and the optimum body composition indices to predict it. Menopause 2010;17:566-70

15. Jesmin S, Islam AS, Akter S, Islam MM, Sultana SN, Yamaguchi N, et al. Metabolic Syndrome among pre- and postmenopausal rural women in Bangladesh: result from a populationbased study. BMC Res Notes. 2013 Dec;6(1):157. 